\title{
Exogenous and Endogenous Nitric Oxide Donors Improve Post-Ischemic Tissue Oxygenation in Early Pancreatic Ischemia/Reperfusion Injury in the Rat
}

\author{
R. Obermaier ${ }^{a} \quad$ E. von Dobschuetz ${ }^{a}$ A. Benthues ${ }^{b} \quad$ N. Ansorge ${ }^{b}$ \\ W. Schareck ${ }^{b}$ U.T. Hopt ${ }^{a}$ S. Benz ${ }^{a}$ \\ aDepartment of Surgery, University of Freiburg, Freiburg, and ${ }^{\mathrm{b}}$ Department of General, Vascular, Thoracic and \\ Transplantation Surgery, University of Rostock, Rostock, Germany
}

\section{Key Words}

Donors, nitric oxide $\cdot$ Nitric oxide .

Ischemia/reperfusion · Pancreas

\begin{abstract}
Introduction: In pancreatic ischemia/reperfusion (IR) injury (IRI) the role of nitric oxide (NO) is not completely understood. Using a rat model of normothermic in situ IRI, the effect of endogenous and exogenous NO donors on post-ischemic tissue oxygenation and tissue damage was investigated. Methods: IR was induced by 2-hour normothermic in situ ischemia of a pancreatic tail segment pedunculated on the splenic vessels with $2 \mathrm{~h}$ of reperfusion in an untreated, an $L$-arginine- and a sodiumnitroprusside-treated group (Wistar rats, $n=7 /$ group). Animals without ischemia served as controls. Tissue oxygenation $\left(\mathrm{pO}_{2 \mathrm{t}}\right.$ ) was monitored using a $\mathrm{pO}_{2}$-sensitive Clark-type electrode. Histological investigation was performed following a semiquantitative score (edema, vacuolization, PMN infiltration, necrosis). Plasma lipase was another marker of organ damage. Results: The administration of $L$-arginine and sodium nitroprusside caused a significant amelioration of the decrease in $\mathrm{pO}_{2 \mathrm{ti}}$ after
\end{abstract}

reperfusion compared to IR animals $(p<0.05)$. Histological damage was also reduced in the NO donor groups $(p<0.05)$. After reperfusion, plasma lipase in the $L$-arginine-treated animals was significantly lower compared to IR and sodium nitroprusside $(p<0.05)$. Conclusions: The administration of both endogenous and exogenous $\mathrm{NO}$ donors is protective in IRI of the rat pancreas which can be seen by an improvement in post-ischemic tissue oxygenation which indicates better nutritive tissue perfusion, amelioration of the histological tissue injury and, in $L$-arginine animals, lower lipase levels. NO donors could be useful in the prevention and reduction of the pancreatic IRI.

Copyright $@ 2004$ S. Karger AG, Basel

\section{Introduction}

Ischemia/reperfusion (IR) injury (IRI) plays an important role in the development of post-transplantation pancreatitis [1] and is an important factor of morbidity after pancreas transplantation [2]. It may also be an important factor in the pathogenesis of acute pancreatitis [3-5]. In different experimental models it has been shown that

\begin{tabular}{ll}
\hline KARGER & ( 2004 S. Karger AG, Basel \\
0014-312X/04/0364-0219\$21.00/0 \\
$\begin{array}{l}\text { Fax +4161306 12 34 } \\
\begin{array}{l}\text { E-Mail karger@karger.ch } \\
\text { www.karger.com }\end{array}\end{array}$ & $\begin{array}{l}\text { Accessible online at: } \\
\text { www.karger.com/esr }\end{array}$
\end{tabular}

Dr. med. Robert Obermaier

Department of Surgery, University of Freiburg

Hugstetter-Strasse 55

DE-79106 Freiburg (Germany)

Tel. +49 761270 2806, Fax +49 761270 2804, E-Mail obermai@ch11.ukl.uni-freiburg.de 
microcirculatory disturbance is one of the most noticeable alterations after reperfusion of the ischemic pancreas [69]. For the first time, we demonstrated the relevance of post-ischemic microcirculation in human pancreas transplantation [10]. We could show that early post-ischemic microcirculatory disorders (decrease in tissue oxygenation, $\mathrm{pO}_{2 \mathrm{ti}}$ ) correlate with a higher inflammatory tissue response (peak C-reactive protein). We have also previously reported that an impairment in microcirculation in the reperfusion period leads to recurrent tissue hypoxia with further depletion of high energy stores, breakdown of transmembrane ion transport, and finally irreversible cell damage [11]. Post-ischemic endothelial dysregulation caused by local mediators might be critical in this process [12] and nitric oxide (NO) in particular has been identified as one of the most important regulators of microcirculation [13]. Although the predominantly protective effects of NO in pancreatic IRI have been published [1416], the role of NO in IRI of the pancreas is still not completely understood and even contradictory effects have been described. This might be due to its multifaceted physiological and pathophysiological effects [17]. In our rat model of normothermic in situ IR [8], we investigated the effect of endogenous and exogenous NO donors on post-ischemic tissue oxygenation and tissue damage.

\section{Methods}

\section{Anesthesia and Monitoring}

Experiments were carried out according to German legislation on the care and use of laboratory animals. Twenty-eight male Wistar rats (Charles River, Sulzfeld, Germany) weighing 290-330 g were included in our study. After overnight fasting but free access to water, the animals were anesthetized by intraperitoneal injection of $60 \mathrm{mg} /$ $\mathrm{kg}$ body weight pentobarbital, and anesthesia was maintained by further intraperitoneal application if necessary. $5 \mu \mathrm{g}$ atropine was injected subcutaneously. The rats were placed on a heating pad to keep rectal temperature between 35.5 and $37.5^{\circ} \mathrm{C}$. For ventilation, tracheostomy was performed and a tube was placed into the trachea. The animals were ventilated with normal air, ventilation setup (Kleintierbeatmungspumpe; TSE, Bad Homburg, Germany; frequency $35-50$ breaths $/ \mathrm{min}$, tidal volume $3.5-5.5 \mathrm{ml}$ ) was adapted if necessary to the following baseline conditions of arterial blood gases: pH $7.4 \pm 0.1, \mathrm{pO}_{2} 75-150 \mathrm{~mm} \mathrm{Hg}, \mathrm{pCO}_{2} 27-45 \mathrm{~mm} \mathrm{Hg}$ (CibaCorning BGA 288 BGS). Polyethylene catheters $(0.5 \mathrm{~mm}$ inner diameter) were placed into the right carotid artery for continuous monitoring of blood pressure and intermittent blood gas samples, and into the left jugular vein for intravenous access (Sirecust 1261; Siemens, Munich, Germany). The intra-arterial access was rinsed continuously with $1 \mathrm{ml} / \mathrm{h}$ of heparinized saline $0.9 \%$ (1,000 IU hepa$\mathrm{rin} / 100 \mathrm{ml}$ ). The intravenous volume was replaced by $3-8 \mathrm{ml} / \mathrm{h}$ of an electrolyte-glucose infusion (contents: $\mathrm{Na} 49.1 \mathrm{mmol} / \mathrm{l}, \mathrm{K}$ $24.9 \mathrm{mmol} / \mathrm{l}, \mathrm{Mg} 2.5 \mathrm{mmol} / \mathrm{l}, \mathrm{Cl} 49.1 \mathrm{mmol} / 1, \mathrm{H}_{2} \mathrm{PO}_{4} 9.9 \mathrm{mmol} / \mathrm{l}$, lactate $20.0 \mathrm{mmol} / 1$, glucose $50 \mathrm{~g} / \mathrm{l}$; Fresenius, Bad Homburg, Germany) using a syringe pump (Vidal medical 1261).

\section{Animal Model}

Preparation of the abdominal situs was performed as previously described in detail [8]. The upper abdomen was opened by transverse laparotomy. The stomach was turned up cranially and fixed on the skin. A pancreatic tail segment was prepared, isolated pedunculated on the splenic vessels, and a microcatheter was inserted into the left gastric artery for organ flushing. In order to allow $\mathrm{pO}_{2 \text { ti }}$ measurements, the pancreas was fixed on an oval plastic pad with sutures to the connective tissue (Prolene 6-0) and splenectomy was performed. $\mathrm{A} \mathrm{pO}_{2}$-sensitive Clark-type probe (LICOX; GMS, Kiel, Germany) was inserted into the pancreatic tissue. This was done via an intravenous cannula which was then retracted (Vasocan Braunuele 20G11/4; Braun, Melsungen, Germany). The probe was fixed to connective tissue on its distal end with a suture (Prolene 6-0). If these procedures caused hematoma in the pancreatic tissue, the experiment was excluded. Following a stabilization period $(\sim 10 \mathrm{~min})$, the organ was flushed $(0.5 \mathrm{ml} \mathrm{NaCl} 0.9 \%)$ via the catheter in the left gastric artery, and an ischemic period of $2 \mathrm{~h}$ was induced by clamping the splenic vessels. The pancreatic tail segment was covered with foil to prevent access of ambient air and replaced into the abdomen which was also covered with foil. The appearance and remaining paleness of the pancreatic tail segment indicated successful flushing. If the paleness disappeared during the ischemic period by retaining low-flow perfusion, the experiment was excluded. After reperfusion the animals were observed for $2 \mathrm{~h}$.

\section{Experimental Protocol}

Animals were randomly assigned to 4 groups $(\mathrm{n}=7$ animals/ group): (1) control (CO), dissection of the pancreatic tail segment, flushing and some seconds of ischemia $(n=7)$ with a 4-hour investigation; (2) IR, 120 min normothermic in situ ischemia of the pancreatic tail segment and $120 \mathrm{~min}$ of reperfusion; (3) $L$-arginine (LA), IR + LA $200 \mathrm{mg} / \mathrm{kg}$ i.v. (in $0.9 \% \mathrm{NaCl}$ ) $30 \mathrm{~min}$ before ischemia and $200 \mathrm{mg} / \mathrm{kg}$ i.v. for $2 \mathrm{~h}$ after reperfusion, and (4) sodium nitroprusside (SN). For ischemia the pancreatic tail segment was flushed with $0.5 \mathrm{ml} 0.12 \% \mathrm{SN}$ solution (in 5\% G5\%) + IR + $600 \mu \mathrm{g} / \mathrm{kg} / \mathrm{h}$ (in $5 \% \mathrm{G} 5 \%$ ) intra-arterially (left gastric artery) after reperfusion.

\section{Tissue $\mathrm{pO}_{2 t i}$}

Tissue $\mathrm{pO}_{2}$ was registered by the implanted Clark-type probe (LICOX; GMS). The values were registered under baseline conditions, $5 \mathrm{~min}$ before and 15,60 and $120 \mathrm{~min}$ after reperfusion.

\section{Blood Samples}

Arterial blood samples $(1 \mathrm{ml})$ were taken before ischemia, 60 and 120 min after reperfusion (Monovette Li-Heparin, Sarstedt, Germany). $2 \mathrm{ml} \mathrm{NaCl} 0.9 \%$ were immediately replaced intravenously. $100 \mu \mathrm{l}$ of the samples were used for blood gas analysis, and $150 \mu \mathrm{l}$ for the measurement of hemoglobin and hematocrit. The remaining 700 $\mu \mathrm{l}$ blood were immediately centrifuged $\left(4,000 \mathrm{~s}^{-1}\right.$ for $\left.6 \mathrm{~min}\right)$, the plasma $(\sim 250 \mu \mathrm{l})$ was aliquoted in portions of $60 \mu \mathrm{l}$ and immediately frozen $\left(-80^{\circ} \mathrm{C}\right)$ for further investigations. The remaining erythrocytes were mixed with $0.5 \mathrm{ml} \mathrm{NaCl} 0.9 \%$ and reinfused. Determination of plasma lipase was done photospectrometrically (Ra 1000, Technika, Berlin, Germany). 
Fig. 1. Tissue oxygenation $\left(\mathrm{pO}_{2 \mathrm{t}} ; \mathrm{mm} \mathrm{Hg}\right)$ : intraparenchymal measurement of tissue oxygenation (Clark-type probe, Licox ${ }^{\circledR}$ ). No differences were seen between all 4 experimental groups under baseline conditions. A significant decrease in $\mathrm{pO}_{2 \text { ti }}$ after induction of ischemia was found in IR, LA and SN ( $\left.{ }^{\#} \mathrm{p}<0.01\right)$ compared to baseline and controls. 15 min after reperfusion, lower $\mathrm{pO}_{2 \mathrm{ti}}$ values were found in IR compared to $\mathrm{CO}$ and $\mathrm{SN}(* \mathrm{p}<0.05) .1$ and $2 \mathrm{~h}$ after reperfusion, a significantly higher $\mathrm{pO}_{2 \mathrm{ti}}$ was found in both NO donor groups compared to IR animals $(\S p<0.05)$. There was no difference between NO donor groups and controls. Values are mean \pm SEM.

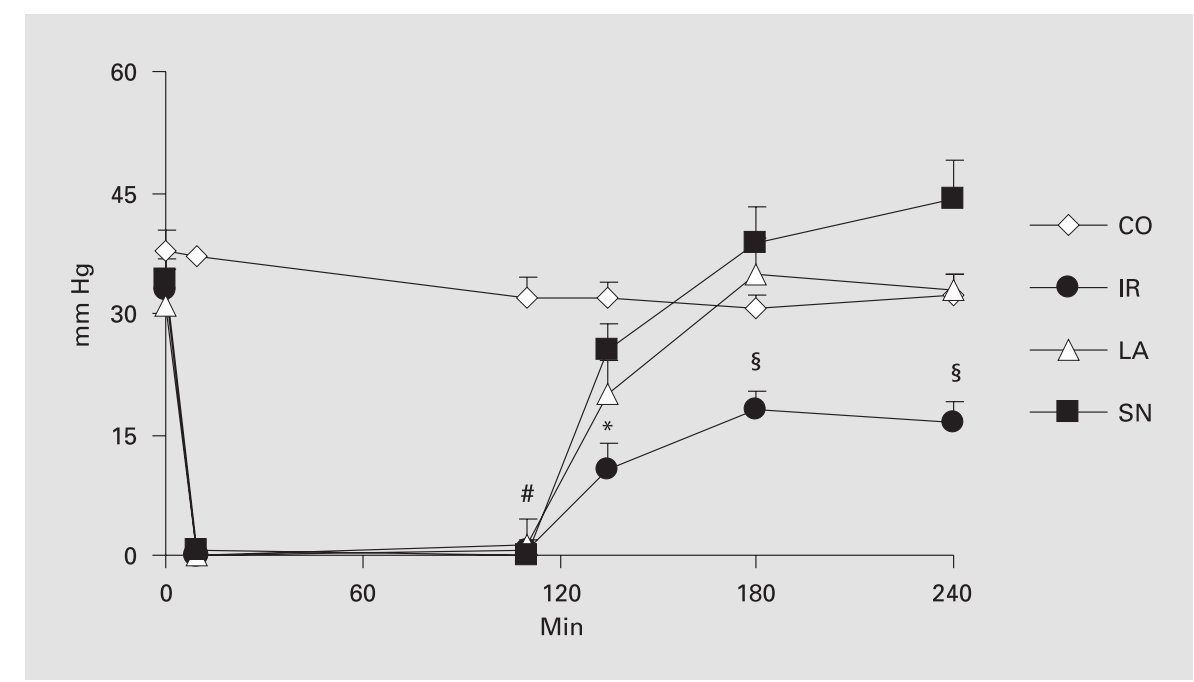

\section{Histology}

At the end of the experiment the pancreatic tail segment was removed for histological investigations. Samples from the pancreatic tail segments were taken from the central parts with a minimum distance of $5 \mathrm{~mm}$ to the edge of the dissection area and were immediately fixed in $4 \%$ neutral buffered formalin. After dehydration and embedding in paraffin the samples were cut $(\sim 4 \mu \mathrm{m}$; Biocut 2035; Lexica, Munich, Germany) and stained with hematoxylin and eosin. Tissue samples for cryo-cuts were blocked onto a metal stamp and immediately frozen in liquid nitrogen. They were cut $(\sim 6 \mu \mathrm{m})$ and subjected to an antibody-specific staining procedure (APAP method, granulocyte-specific antibody RK4; Dianova, Hamburg, Germany). The histomorphological characteristics were evaluated blindly according to a previously described semiquantitative score including edema, vacuolization, polymorphonuclear neutrophil (PMN) infiltration and necrosis [8].

\section{Statistics}

Means were compared by the Mann-Whitney U test for independent samples and by the Wilcoxon rank test for grouped samples. Statistical significance was defined as $p<0.05$. Data are presented as mean $\pm \mathrm{SEM}$; only histology is shown as mean $\pm \mathrm{SD}$.

\section{Results}

\section{Mean Arterial Pressure}

At each time point, the difference in mean arterial pressure (MAP) between all experimental groups did not reach statistical significance. Only in the IR group was the MAP significantly lower $2 \mathrm{~h}$ after reperfusion compared to baseline measurements. In the other groups the changes in MAP in the course of the experiments were not significant (table 1).

NO Donors and Pancreatic

Ischemia/Reperfusion Injury
Table 1. Mean arterial pressure (MAP). Values are mean \pm SD

\begin{tabular}{llll}
\hline Variables & Baseline & \multicolumn{2}{l}{ Reperfusion } \\
\cline { 3 - 4 } & & $60 \mathrm{~min}$ & $120 \mathrm{~min}$ \\
\hline CO & $105.3 \pm 5$ & $87.4 \pm 6$ & $88.1 \pm 6$ \\
IR & $100.3 \pm 3$ & $82.7 \pm 6$ & $76.3 \pm 2^{*}$ \\
SN & $103.1 \pm 4$ & $84.9 \pm 4$ & $86.7 \pm 4$ \\
LA & $106.6 \pm 4$ & $85.1 \pm 5$ & $88.6 \pm 6$ \\
\hline
\end{tabular}

$* \mathrm{p}<0.05$ vs. IR baseline.

\section{Tissue Oxygenation}

No differences were seen between all 4 experimental groups under baseline conditions (CO $37.8 \pm 3$, IR 32.8 \pm 5 , LA $31.1 \pm 5$, and SN $34.3 \pm 3 \mathrm{~mm} \mathrm{Hg}$ ). After induction of ischemia, $\mathrm{pO}_{2 \mathrm{ti}}$ decreased almost to zero until reperfusion. $15 \mathrm{~min}$ after reperfusion, $\mathrm{pO}_{2 \mathrm{ti}}$ was rising and reached significantly higher values in $\mathrm{SN}$ animals but not in the IR group (IR $10.8 \pm 3$, SN $25.4 \pm 4$; p < 0.05). 1 and $2 \mathrm{~h}$ after reperfusion both the NO donor groups reached control and baseline values and were significantly higher $(1 \mathrm{~h}$ : CO $30.6 \pm 2$, IR $18.0 \pm 2$, LA $34.5 \pm 5$, SN $38.6 \pm 5 ; 2$ h: CO $32.4 \pm 2$, IR $16.4 \pm 3$, LA $32.8 \pm 2$, SN $44.3 \pm 5 ; \mathrm{p}<0.05$ ) than in the IR group (fig. 1).

\section{Light Microscopy}

The histological damage in the pancreas tail segment subjected to $2 \mathrm{~h}$ of normothermic in situ ischemia was highest in IR animals, and was significantly lower in both NO donor groups. SN showed higher scores than the $\mathrm{CO}$ 
Fig. 2. Histological damage (score points): semiquantitative score (edema, vacuolization, PMN infiltration, necrosis and total score) at the end of the experiments. Significantly more damage (total score) was found in IR compared to all other groups $(* \mathrm{p}<$ $0.05)$. The $\mathrm{SN}$ group had more histological damage compared to control animals ${ }^{\#} \mathrm{p}<$ $0.05)$.

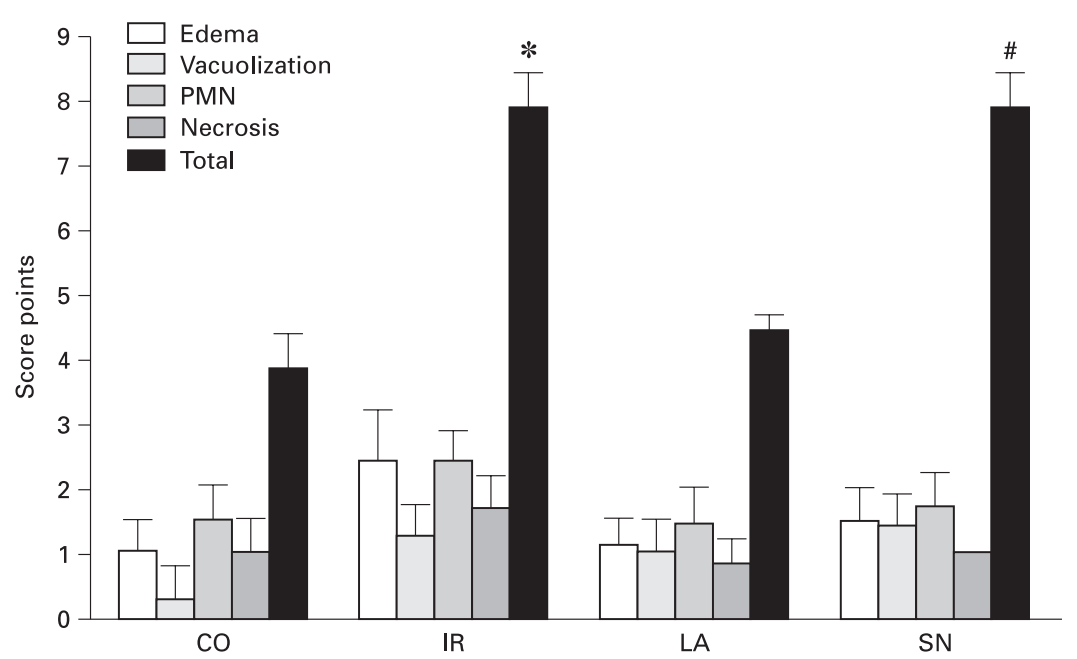

$\mathrm{CO}$

IR

LA

SN

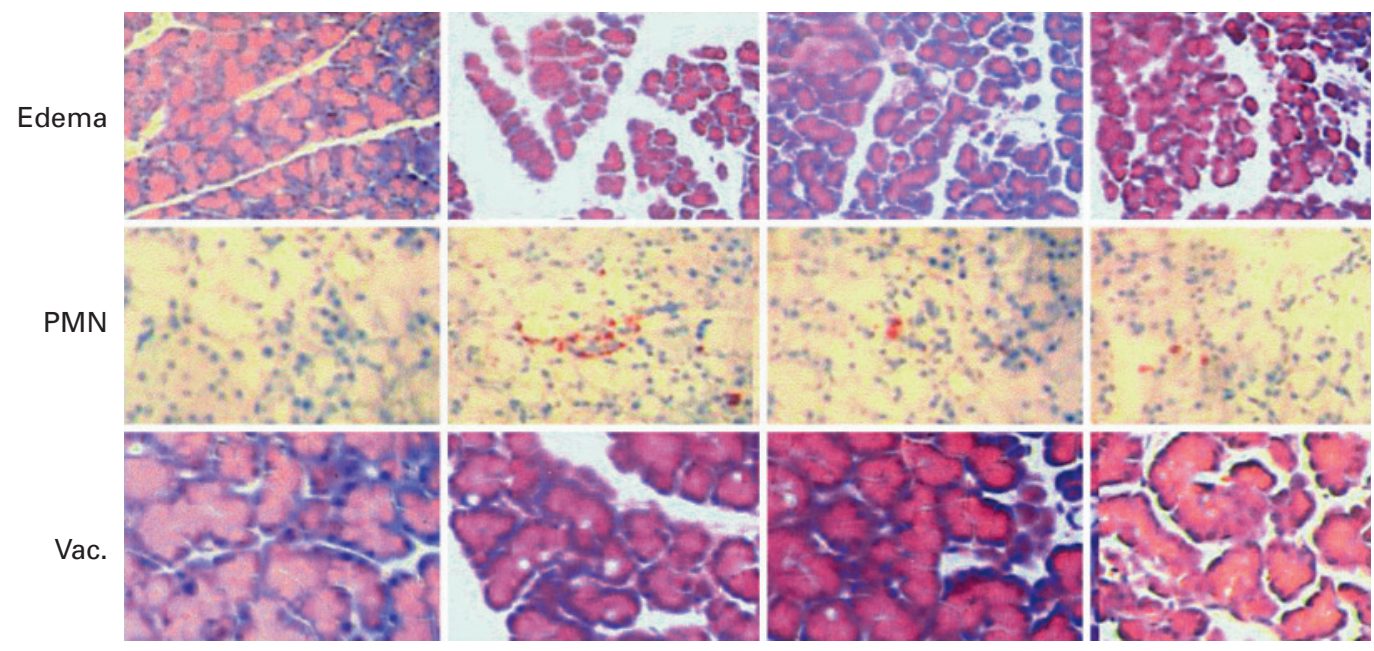

Fig. 3. Exemplary histological sections depicting the differences between the experimental groups of edema and vacuolization. HE. PMN infiltration: cryo-sections, granulocyte-specific antibody RK4 (Dianova, Hamburg, Germany).

animals. Administration of LA reduced histological damage, and there was no significant difference to $\mathrm{CO}$ animals $($ CO $3.9 \pm 1$, IR $7.9 \pm 2$, LA $4.4 \pm 1$, SN $5.6 \pm 1$ score points, mean $\pm \mathrm{SD} ; \mathrm{p}<0.05)$. Between $\mathrm{SN}$ and LA there was no significant difference (fig. 2, 3).

\section{Lipase}

Under baseline conditions there was no significant difference between all 4 experimental groups (CO $154 \pm 58$, IR $193 \pm 39$, LA $96 \pm 11$, SN $123 \pm 17$ U/l, mean \pm SEM). Only in CO animals was no significant increase 
Fig. 4. Lipase (U/1): no significant increase in lipase was seen in the control animals. A significant increase was found in LA, IR and $\mathrm{SN}$ animals $(* \mathrm{p}<0.05): 1$ and $2 \mathrm{~h}$ after reperfusion, higher lipase values were found in IR and SN compared to CO and LA ( ${ }^{\#} \mathrm{p}<$ $0.01)$. No significant difference was found between LA and CO.

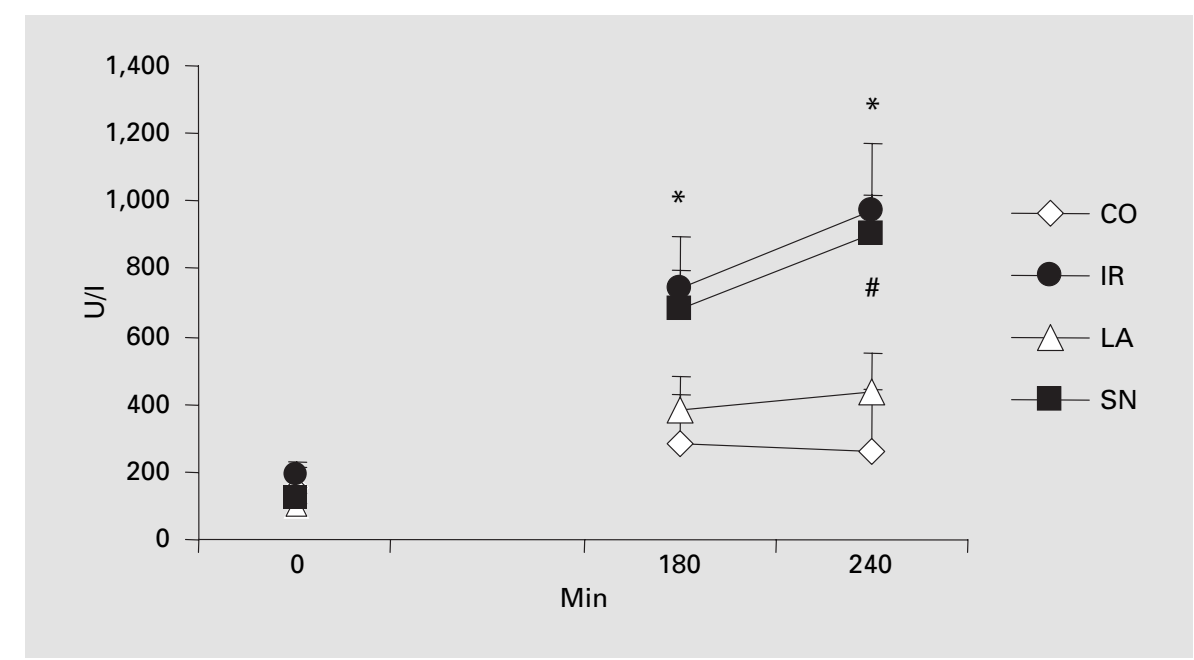

found in the course of the experiment $(1 \mathrm{~h}$ : $284 \pm 144$; $2 \mathrm{~h}: 261 \pm 184)$. In the other groups the increase was significant at $1 \mathrm{~h}$ (IR $744 \pm 50$, SN $685 \pm 213, \mathrm{p}<0.01$, and LA $386 \pm 96, \mathrm{p}<0.05$ ) and $2 \mathrm{~h}$ after reperfusion (IR 968 \pm 52 , SN $900 \pm 270, \mathrm{p}<0.01$, and LA $440 \pm 110, \mathrm{p}<$ 0.05; fig. 4).

\section{Discussion}

In the present study we could demonstrate a significant protective effect of endogenous and exogenous NO donors (sodium nitroprusside and LA) on post-ischemic tissue oxygenation and tissue injury (histological damage and lipase) in our model [8] of normothermic in situ IRI.

Pancreatic IRI is a multifaceted pathophysiological event leading to graft pancreatitis after human pancreas transplantation [18]. Microcirculatory disturbance is one of the most important pathogenetic factors in IRI of the pancreas [6-8] and has even been shown in clinical pancreas transplantation [19]. To quantify microcirculatory disturbances in our experiments, we used tissue oximetry, for which a highly significantly correlation with tissue blood flow has recently been shown [20]. Early microcirculatory disorders correlate with post-ischemic tissue damage; therefore, improvement in post-ischemic microcirculation is one of the major goals in the investigation of pancreatic IRI. In our experiments in the IR group, a reduced tissue $\mathrm{pO}_{2}$ was seen after reperfusion, indicating a decrease in nutritive organ perfusion and confirming the impairment in microcirculation during this period. This is also demonstrated by the organ damage seen histologi- cally and by the lipase values. Why the protective effect on lipase activity is completely missing in the $\mathrm{SN}$ group remains speculation; the decrease in lipase activity in sodium-nitroprusside-treated animals did not reach statistical significance compared to IR animals. One possibility could be the form of application (local intra-arterial application of high doses). However, also in clinical practice, the value of lipase activity is overestimated in predicting the dimension of pancreatitis. Here the value of lipase activity does not correlate with the extent of pancreatitis (e.g. amount of pancreatic necrosis) [21].

NO is involved in the physiologic regulation of blood pressure via vascular smooth muscle tone and it is crucially involved in the physiological regulation of microvascular perfusion. These effects are mediated by the activation of the soluble guanylate cyclase and consecutive modulation of ion channels by cyclic guanosine $3^{\prime}, 5^{\prime}$-monophosphate, and it is well known that NO leads to vasodilatation and thus increases tissue perfusion [17].

Another important mechanism of NO donors is the inhibition of PMN activation and infiltration. NO inhibits neutrophil-endothelial interaction by inhibition of leukocyte activation and expression of adhesion molecules, and it also interferes with platelet aggregation [22, 23]. This is important because to date it is assumed that PMN activation is triggered at the time of reperfusion by the release of reactive oxygen species followed by the activation of proinflammatory factors (e.g. NFKB) and the expression of endothelial adhesion molecules (intercellular adhesion molecule, P-selectin) [24, 25]. Recently we showed that immediately after reperfusion PMN infiltration was not significantly influenced by SN and LA [15]. 
We drew the conclusion that endothelial activation and thus endothelial adhesiveness must have taken place already during the ischemic period. Our findings are also supported by the results of other groups who could demonstrate an activation of NFKB during ischemia before reperfusion [26, 27]. In pancreatic IRI it seems quite clear that under most circumstances supplementation of $\mathrm{NO}$ is protective [15]. In our experiments the direct (exogenous) NO donor sodium nitroprusside as well as the substrate of the NO synthases, LA, significantly attenuated the postischemic impairment of tissue oxygenation and thus microcirculation. This is in accordance with previous reports. For the application of LA, Vollmar et al. [16] reported a decrease in leukocyte-dependent tissue injury and an attenuation of microvascular reperfusion injury in a model of pancreas transplantation in the rat. The effect was demonstrated only in capillary dilatation and not in increasing functional capillary density. Data from Tanaka et al. [28] also suggest a beneficial effect of NO in a model of incomplete pancreatic IRI, showing a reduction in lipase release and amelioration of tissue injury by SN. For sodium nitroprusside we were able to show a protective effect in our porcine model of pancreatic IRI. This was demonstrated in morphology, tissue oxygenation, blood flow and lipase release [14]. In the same model we were recently able to also prove a protective effect of LA. Although no significant effect on tissue oxygenation could be demonstrated, a significant effect on lipase release, morphological tissue damage and especially PMN infiltration was shown [15]. The above-mentioned porcine model is of high experimental expenditure and there are only limited porcine antibodies for further investigations. Since mechanisms and pharmaceutical effects in animal experiments cannot be automatically deduced from other species and we wanted to investigate the comparability of our 2 animal models, we decided to repeat NO treatment studies in our small animal model. There is an important difference in the setup of the 2 animal models. In our rat experiments the chosen period of ischemia was $2 \mathrm{~h}$, in contrast to $3 \mathrm{~h}$ in porcine experiments. $3 \mathrm{~h}$ of ischemia in pigs caused tissue damage analogous to severe acute pancreatitis with marked necrosis. In contrast, the 2-hour ischemic damage of the rat experiments is more in accordance with the morphological changes in post-ischemic pancreatitis in human pancreas transplantation $1 \mathrm{~h}$ after reperfusion [12]. Thus the tissue injury of the rat model is probably more equivalent to the early situation in human pancreas transplantation.

NO donors are known to cause hypotension. In pilot dose-finding experiments we could define the amounts of $\mathrm{SN}$ and LA that effectively ameliorate IRI without depression of MAP (data not shown). In clinical studies, LA was used in comparable doses, and no effect on MAP and heart rate could be found, nor were there any other side effects [29]; so the administration of LA seems to be more practical. In humans, sodium nitroprusside has a stronger hypotensive effect and should not be used for clinical studies because it seems to have no advantage over LA.

In conclusion, a significant protective effect of exogenous and endogenous NO administration could be proven. Protective effects were seen in important pathogenetic factors of the development of graft pancreatitis (tissue oxygenation, histological damage, lipase activity). An improvement in post-ischemic microcirculation and a reduction in the inflammatory tissue response are important points to reduce morbidity after human pancreas transplantation, and LA should be considered for clinical studies in pancreas transplantation.

\section{References}

1 Benz S, Pfeffer F, Buesing M, Becker H, Hopt UT: Lokale und systemische Komplikationen nach kombinierter Nieren-/Pankreas-Transplantation. Chir Gastroenterol 1996;12:44-45.

$\checkmark 2$ Grewal HP, Garland L, Novak K, Gaber L, Tolley EA, Gaber AO: Risk factors for postimplantation pancreatitis and pancreatic thrombosis in pancreas transplant recipients. Transplantation 1993;56:609-612.

$\checkmark 3$ Klar E, Messmer K, Warshaw AL, Herfarth C: Pancreatic ischaemia in experimental acute pancreatitis: Mechanism, significance and therapy. Br J Surg 1990;77:1205-1210.
4 Sunamura M, Yamauchi K, Shibuya K, Chen H, Ding L, Takeda K, Kobari M, Matsuno S: Pancreatic microcirculation in acute pancreatitis. J Hepatobiliary Pancreat Surg 1998;5:6268.

5 Menger MD, Plusczyk T, Vollmar B: Microcirculatory derangements in acute pancreatitis. $\mathrm{J}$ Hepatobiliary Pancreat Surg 2001;8:187-194.

-6 Hoffmann TF, Leiderer R, Waldner H, Arbogast $\mathrm{S}$, Messmer K: Ischemia reperfusion of the pancreas: A new in vivo model for acute pancreatitis in rats. Res Exp Med (Berl) 1995;195: 125-144.
7 Benz S, Schnabel R, Morgenroth K, Weber H, Pfeffer F, Hopt UT: Ischemia/reperfusion injury of the pancreas: A new animal model. J Surg Res 1998;75:109-115.

$>8$ Obermaier R, Benz S, Kortmann B, Benthues A, Ansorge N, Hopt U: Ischemia/reperfusion induced pancreatitis in rats: A new model of complete normothermic in-situ ischemia of a pancreatic tail segment. Clin Exp Med 2001;1: 51-59.

$\checkmark 9$ Obermaier R, Benz S, von Dobschuetz E, Drognitz O, Schareck W, Jonas L, Messmer K, Hopt UT: Characterisation of microcirculatory disturbance in a novel model of pancreatic ischemia-reperfusion using intravital fluorescence-microscopy. Pancreas 2002;25:142-148.

Obermaier/von Dobschuetz/Benthues/ Ansorge/Schareck/Hopt/Benz 
10 Benz S, Bergt S, Obermaier R, Wiessner R, Pfeffer F, Schareck W, Hopt UT: Impairment of microcirculation in the early reperfusion period predicts the degree of graft pancreatitis in clinical pancreas transplantation. Transplantation 2001;71:759-763.

11 Benz S, Wiessner R, Obermaier R, Pfeffer F, Hopt U: Microcirculatory events in ischemia/ reperfusion injury defined by continuous tissue oximetry. Transpl Int 2002;15:173-179.

12 Benz S: Pathophysiologie des Ischämie/Reperfusionsschadens am Pankreas; Habilitationsschrift, Universität Rostock, 2000.

13 Moncada S, Palmer RM, Higgs EA: The discovery of nitric oxide as the endogenous nitrovasodilator. Hypertension 1988;12:365-372.

$\checkmark 14$ Benz S, Schnabel R, Weber H, Pfeffer F, Wiesner R, von Breitenbuch P, Nizze H, Schareck W, Hopt UT: The nitric oxide donor sodium nitroprusside is protective in ischemia/ reperfusion injury of the pancreas. Transplantation 1998;66:994-999.

- 15 Benz S, Obermaier R, Wiessner R, von Breitenbuch P, Burska D, Weber H, Schnabel R, Mayer J, Pfeffer F, Nizze H, Hopt UT: Effect of nitric oxide in ischemia/reperfusion of the pancreas. J Surg Res 2002;106:46-53.

-16 Vollmar B, Janata J, Yamauchi JI, Menger MD: Attenuation of microvascular reperfusion injury in rat pancreas transplantation by $L$ arginine. Transplantation 1999;67:950-955.
17 Moncada S, Radomski MW, Palmer RM: Endothelium-derived relaxing factor. Identification as nitric oxide and role in the control of vascular tone and platelet function. Biochem Pharmacol 1988;37:2495-2501.

18 Büsing M, Hopt UT, Quacken M, Becker HD, Morgenroth K: Morphological studies of graft pancreatitis following pancreas transplantation. Br J Surg 1993;80:1170-1173.

19 Benz S, Bergt S, Obermaier R, Pfeffer F, Hopt UT: Impairment of pancreatic microcirculation in the early reperfusion period correlates with the degree of organ damage in clinical pancreas transplantation. Shock 2000; 13(suppl):60.

20 Urakami A, Hirai R, Ota T, Soga H, Nawa S, Shimizu N: Continuous measurement of tissue oxygen and carbon dioxide gas tensions in dog liver in ischemia/reperfusion. Acta Med Okayama 1996;50:285-292.

21 Lankisch PG, Blum T, Maisonneuve P, Lowenfels AB: Severe acute pancreatitis: When to be concerned? Pancreatology 2003;3:102-110.

22 Moilanen E, Vuorinen P, Kankaanranta $\mathrm{H}$, Metsa-Ketela T, Vapaatalo H: Inhibition by nitric oxide-donors of human polymorphonuclear leucocyte functions. Br J Pharmacol 1993; 109:852-858.

23 Radomski MW, Palmer RM, Moncada S: Modulation of platelet aggregation by an $L$ arginine-nitric oxide pathway. Trends Pharmacol Sci 1991;12:87-88.
24 Liu P, Xu B, Hock CE, Nagele R, Sun FF, Wong PY: NO modulates P-selectin and ICAM-1 mRNA expression and hemodynamic alterations in hepatic I/R. Am J Physiol 1998; 275:H2191-H2198.

25 Shin WS, Hong YH, Peng HB, De Caterina R, Libby P, Liao JK: Nitric oxide attenuates vascular smooth muscle cell activation by interferon-gamma. The role of constitutive NF-kappa B activity. J Biol Chem 1996;271:1131711324.

26 Kupatt C, Habazettl H, Goedecke A, Wolf DA, Zahler S, Boekstegers P, Kelly RA, Becker BF: Tumor necrosis factor-alpha contributes to ischemia- and reperfusion-induced endothelial activation in isolated hearts. Circ Res 1999;84 392-400.

27 Kacimi R, Karliner JS, Koudssi F, Long CS: Expression and regulation of adhesion molecules in cardiac cells by cytokines: Response to acute hypoxia. Circ Res 1998;82:576-586.

28 Tanaka S, Kamiike W, Kosaka H, Ito T, Kumura E, Shiga T, Matsuda H: Detection of nitric oxide production and its role in pancreatic ischemia-reperfusion in rats. Am $\mathbf{J}$ Physiol 1996;271:G405-G409.

29 Zimmermann C, Haberl RL: L-arginine improves diminished cerebral $\mathrm{CO}_{2}$ reactivity in patients. Stroke 2003;34:643-647. 